\title{
Da formação docente em serviço aos espaços de criação em sala de aula
}

Paloma Dias Silveira

Doutoranda em Educação pela Universidade Federal do Rio Grande do

Sul

Margarete Axt

Professora Titular da Universidade Federal do Rio Grande do Sul

Doutora em Linguística e Letras pela Pontifícia Universidade Católica do

Rio Grande do Sul

\section{Resumo}

A pesquisa buscou traçar percursos da abertura de espaços de criação numa sala de aula do ensino fundamental (terceiro ano), na qual a professora responsável participa de um projeto de formação continuada que investe na vivência de uma perspectiva ético-estética na relação com o outro. O material que analisamos trata-se de enunciados obtidos através de registros audiovisuais em sala de aula e registros escritos em diário de campo da pesquisa. A formulação teórica remete aos estudos de Mikhail Bakhtin. As conclusões apontam para a relevância de dar visibilidade ao movimento de instauração de um ato ético de escuta em sala de aula

Palavras-chave: Ética; Estética; Formação Docente.

\section{Résumé}

La recherche a cherché à dessiner des parcours de l'ouverture d'espaces de création dans une salle de classe de l'enseignement élémentaire (troisième année), dans laquelle l'enseignante participe à un projet de formation continue qui investit au vécu d'une perspective éthique-esthétique dans la relation avec l'autrui. Le matériel que nous analisons consiste à des énoncés obtenus à travers d'enregistrements audiovisuels en salle de classe ainsi que par des enregistrements écrits dans un journal de champ de la recherche. La formulation théorique fait référence aux études de Mikhail Bakhtin. Les conclusions pointent sur l'importance de rendre visible le mouvement d'instauration d'un acte éthique d'écoute en salle de classe.

Mots-clés: Ethique; Esthétique; Formation Enseignant. 


\section{Introdução}

presente pesquisa busca traçar percursos da abertura de
espaços de criação numa sala de aula do ensino fundamental
(escola pública), na qual a professora responsável participa de um projeto de formação continuada em serviço, o Civitas, que investe na vivência de uma perspectiva ético-estética na relação com o outro. Nossa arquitetônica teórica se apóia nos estudos do filósofo da linguagem Mikhail Bakhtin, operando com os conceitos de ética, estética, ideias e carnavalização.

Do ponto de vista analítico-metodológico, trabalhamos com enunciados produzidos pelos alunos e pela professora da turma de terceiro ano que acompanhamos, bem como com registros escritos no diário de campo da pesquisa. Na primeira seção, investimos numa abordagem dos conceitos tendo em vista a sua posterior articulação no curso das análises.

Na segunda seção, apresentamos nossa perspectiva metodológica, destacando o seu cunho dialógico. Na terceira seção, à luz dos referenciais analisamos os materiais empíricos que consistem em transcrições de diálogos das crianças complementados com observações extraídas do já referido diário.

\section{O aporte teórico conceitual em Mikhail Bakhtin}

Destacamos, entre as formulações que perpassam as obras de Bakhtin e que constituem o referencial deste estudo: a ética, a estética, as ideias e a carnavalização.

\subsection{A ética e a estética}

Mikhail Bakhtin, um jovem estudioso de filosofia da linguagem no contexto soviético dos anos 20, desenvolve a questão ética em sua obra Para uma filosofia do Ato, discutindo centralmente o ato ético: ato ético enquanto ato efetuado com base no dever de agir responsavelmente, i.e. de 
“responsar" (responder obrigatoriamente), tanto a si mesmo, no processo de auto-realização da própria vida; quanto ao outro, ao qual se destina todo agir relacional em contexto.

O ato é por ele visto como sendo absolutamente situado, o que conduz a uma acepção de ética que não pode estar desvinculada dos contextos de realização do agir. Enquanto pensada em relação ao ser em processo de devir (um ser-sujeito que se constitui processualmente num tempo e circunstâncias particulares, mas permanecendo sempre em aberto, sempre inacabado), a ética não é tomada pelo autor como objeto de abstração teórica em direção a proposições universais: antes, opera com o entendimento de que a atitude ética passa pela tomada de uma posição integralmente assumida pelo ser em processo de Ser (Ser-evento, em devir), e que é norteada pela especificidade de sua vida na relação com o outro.

Bakhtin afirma que somos responsáveis pelas formas de diálogo que estabelecemos com o mundo através de nossos atos, o que envolve necessariamente um conjunto de escolhas baseadas num compromisso (ético) com esse mundo-outro: ou seja, um ato emerge como ato ético situado e responsável, pelo reconhecimento do lugar único que a vida concreta de cada sujeito singular ocupa, enquanto um "eu”, no plano da realidade movente (Ser-evento, em devir), e dos efeitos que advêm sobre as relações com o outro.

A ideia de singularidade funda-se na compreensão do lugar único do ser, na sua unicidade: “[...] eu ocupo um lugar no Ser, único e irrepetível, um lugar que não pode ser tomado por ninguém mais e que é impenetrável a qualquer outra pessoa” (Bakhtin, s/d:58). E é desse lugar único que ocupa no Ser, que o "eu" em sua singularidade realiza o ato ético de encontro relacional com o não-eu, o outro, reconhecendo-o e o constituindo em sua existência:

Que eu, do meu lugar único no Ser, simplesmente veja e conheça um outro, que eu não o esqueça, que para mim, também, ele exista - isso é algo que apenas eu posso fazer por ele no dado momento em todo o Ser: esta é a ação que faz o ser 
dele mais completo, a ação que é absolutamente proveitosa e nova, e que só é possível por mim (BAKHTIN, s/d, p. 59-60).

Abrindo um parêntese, nas palavras acima Bakhtin já está indo em direção a um conceito que irá permear suas obras, ainda que com distintas nuances, o excedente de visão. Esse conceito continuará reafirmando a noção de singularidade e de insubstitutibilidade do lugar do ser no mundo, um lugar único, que possibilita ao ser, por essa razão, um excedente de visão em relação ao outro. Enfatizará, então, que, do lugar ocupado pelo ser, este tem acesso a uma visão que nenhum outro ser pode ter, completando-o. Ora, ver no outro algo que ele próprio não vê só é possível de uma posição a ele exterior, distanciada, o que lhe assegura (ao ser) um lugar contemplativo, exotópico: deste lugar posso completar o outro com algo de uma visão que apenas eu possuo, elementos transgredientes advindos da minha posição única no mundo; de igual maneira, o outro pode me completar com algo que é inacessível ao meu próprio ver. Finalizando o parêntese, não se pode perder a oportunidade de considerar que esse excedente de visão compõe (ainda que implicitamente, num primeiro momento) o conceito do que deve ser entendido como visão estética em Bakhtin, já desde a sua obra juvenil Para uma filosofia do ato.

Voltando à afirmação da unicidade, Bakhtin enfatiza o não-álibi do ser-sujeito no Ser em processo, em devir. Ao existir, o ser está automaticamente comprometido. Este comprometimento passa pela sua relação com o outro (não-eu), que ora pode ser entendido como pequeno outro, ora como grande Outro. Amorim (2009) fala do outro como ser concreto e singular e do Outro como ser da cultura, o conhecimento objetivo, abstrato e universal. Assim, o ser real e único na sua existência estaria duplamente comprometido, detendo a possibilidade de, ao realizar sua singularidade, ao reconhecê-la, completar o outro/Outro com algo que somente ele poderia oferecer. A não-indiferença do ser afirma a potência de uma singularidade participante, ativa e generosa.

O ser completa e é completado na relação com a alteridade, não existindo álibi para justificar sua ausência nesta relação, para justificar seu 
não-pensar e seu não-criar. Para Bakhtin (s/d:51): “O experimentar ativo de uma experiência, o pensar ativo de um pensamento, significa não estar de modo algum indiferente a ele, significa afirmá-lo de uma maneira emocional-volitiva”. Assim, o ser é responsável pelo seu ato e não há álibi para que ele não o realize e não o assuma. Ao assumi-lo, ao assiná-lo, o ser age eticamente.

No entanto, seria um equívoco limitar a ética pensada por Bakhtin como uma ética do agir independente do seu conteúdo-sentido, já que a questão do conteúdo-sentido é insistentemente retomada na sua obra. O estudioso não restringe o ético ao que é considerado “bom”, mas expressa, antes de tudo, a centralidade do caráter contextual e situado de cada ato na avaliação de seu conteúdo-sentido, levando à impossibilidade de que uma norma transcendental-formal venha a definir o que é "bom” ou "mau”, de acordo com regras pré-configuradas. Assim: “Quando separamos abstratamente o conteúdo de uma experiência vivida de sua experiência real, o conteúdo se apresenta a nós como algo absolutamente indiferente ao valor enquanto valor real e afirmado” (Bakhtin, s/d:51).

Bakhtin também irá discutir em sua obra a relação entre o ético e o estético. Conforme explicita Sobral, o estético em Bakhtin “... resulta de um processo que busca representar o mundo do ponto de vista da ação exotópica do autor...” (2007:108).

$\mathrm{O}$ ato ético, enquanto ato reconhecido e assinado, orientado ao outro/Outro, é condição de possibilidade para a realização estética. Encontramos a orientação desta reflexão inicialmente em Para uma filosofia do ato, e posteriormente em $O$ autor e a personagem, texto também escrito na década de 20, em que é discutida a relação entre o autor e o personagem na obra artística. Bakhtin analisa que o autor ocupa um lugar exotópico em relação ao personagem, fora da própria obra, assegurando-lhe (ao autor) acesso a uma posição contemplativa, capaz de abarcar uma totalidade inacessível ao personagem, garantindo, por esse excedente de visão, um acabamento de conjunto da obra. 
O princípio do acabamento estético, para Bakhtin, supõe a noção de compenetração, ou seja, o estabelecimento de uma relação de empatia com o personagem: "Eu devo vivenciar - ver e inteirar-me - o que ele vivencia, colocar-me no lugar dele, como que coincidir com ele” (2003:23). Já a noção de empatia, trazida por primeira vez em Para uma filosofia do ato, está para além da relação autor-personagem, mas também invocando compor um momento essencial da contemplação estética, momento de fusão com o objeto da visão, no processo de vê-lo de dentro de sua própria essência. Para ele, a empatia “...é um momento abstrato do ato unitário da atividade estética, e não deveria ser pensada como um período temporal; os momentos de empatia e de objetivação interpenetram-se mutuamente” (Bakhtin, s/d:33).

Logo, a atividade estética, no que concerne à relação autorpersonagem, realizar-se-ia nesse movimento em que o autor entra no mundo do personagem, vivencia seu interior empaticamente (vale dizer, eticamente), e, ao mesmo tempo, retorna ao seu lugar fora do personagem para dar acabamento (estético) ao material da compenetração: completa tal material com os elementos transgredientes que encontra em sua posição exterior à obra, a partir de seu lugar histórico e único no Ser em processo (e pela via contemplativa propiciada por seu excedente de visão). O mesmo, em outra escala, se daria, por suposto, com a relação eu-outro/Outro.

Contudo, observe-se que esta entrada no mundo, seja do outro/Outro, seja do personagem, esta fusão, compenetração, empatia... não significa uma identificação completa, plenamente realizada, pois se o fosse, contradiria a tese bakhtiniana do "não-álibi” no Ser, um podendo assumir o lugar do outro, todos se equivalendo entre si, apagando-se os traços de singularidade e de unicidade no Ser:

O ato ético da empatia é a chave ofertada generosamente por Bakhtin para que o um tenha acesso ao lugar do outro, embora a empatia não possa prover uma identificação completa e plena com este lugar do outro, com toda a arquitetônica do outro. $\mathrm{Na}$ verdade, uma identificação empática completa e plena com o lugar do outro provocaria, para o um a perda de seu próprio 
lugar único: perder-se no outro, no não-eu, seria também desrealizar-se (no limite, a sombra, a loucura, o suicídio...). (Axt, 2011).

Em suma, ato ético de empatia e contemplação estética constituem "dois sentidos de um mesmo movimento, duas faces de uma mesma interface relacional" (Axt, 2011), seja entre do um com seu outro/Outro, seja do autor com seu personagem.

\subsection{As ideias}

A partir de sua análise sobre a poética de Fiodór Dostoiévski, Bakhtin compõe um conceito de ideia associado ao movimento do pensamento, do processo criador na vida e na arte. Este conceito, ainda que à primeira vista pareça incipiente na sua obra, diz de um processo complexo em que uma ideia nasce, vive e ganha força de originalidade.

Bakhtin comenta, na obra Problemas da Poética de Dostoiévski (2002), que o romancista apresenta uma "profunda compreensão da natureza dialógica do pensamento humano, da natureza dialógica da ideia. Dostoievski conseguiu ver, descobrir e mostrar o verdadeiro campo da vida da ideia” (Bakhtin, 2002:86). Para construir as ideias de seus personagens, Dostoiévski dialogava com diferentes vozes, diferentes perspectivas/modos de ver o mundo, destituindo-as de sua forma fechada, para torná-las o que Bakhtin conceitua como ideias-força, ideias que ganham vida no diálogo entre as consciências.

É interessante observar que “... Dostoiévski nunca criava as suas imagens das idéias a partir do nada, nunca as "inventava", como o artista não inventa as pessoas que retrata” (ibid:89). Bakhtin aponta, como evidência nessa direção, alguns modelos prototípicos que operam como base para as ideias dos personagens dostoievskianos, como por exemplo: as ideias de Napoleão III $^{1}$ estariam operando como protótipo para as ideias de Rodion Românovitch Raskólnikov, personagem do conhecido romance Crime e Castigo, publicado em 1866.

${ }^{1}$ Publicadas no livro A história de Júlio César. Segundo Bakhtin, este livro foi publicado em 1865 e obteve grande repercussão na Rússia. 
Dostoiévski parte, então, de ideias-protótipos, com base no seu diálogo com diferentes vozes/perspectivas, tanto as de sua época quanto outras mais distantes, logo reelaborando-as artisticamente. Para Bakhtin (ibid:88),

... ao perder o seu acabamento monológico teórico-abstrato, que satisfaz apenas a uma consciência, a idéia assume uma complexidade contraditória e a viva variedade de idéia-força, que nasce, vive e atua no grande diálogo da época e guarda semelhança com as idéias cognatas de outras épocas.

O escritor romancista reelabora as ideias-protótipo, tornando-as ideias-força, verdadeiras imagens artísticas. Este movimento das ideias nos remete ao exemplo trazido por Marília Amorim, com relação ao trabalho de Pablo Picasso. Na pintura A mulher que chora (1937), Picasso retrata sua esposa Dora Mäar. Segundo Amorim (2006, p. 97), Dora Mäar, em A mulher que chora, “... é definida pelas lágrimas, pelo seu choro, e toda a composição do retrato está a serviço desta única idéia [...] A decomposição dos traços, os traços rápidos e espessos das linhas constroem, então, um outro movimento”.

Conforme a autora, Picasso pintou o sofrimento de sua esposa, uma mulher vivendo na época da Guerra Civil Espanhola e que, ao final da vida, tornava-se cada vez mais depressiva. Picasso dialogou com a expressão de Dora ao observar a guerra, dialogou com sua tristeza, sua angústia. Para Amorim (2006:98), pode-se afirmar que “... Picasso, de seu lugar exterior, captou algo de profundo e essencial dessa mulher. E que até anteviu que as lágrimas e o sofrimento viriam efetivamente a definir o sentido da existência de Dora Mäar”.

Picasso não representou um rosto acabado, estático, pois a imagem de Dora é puro movimento. Entendemos que o pintor parte de uma ideiaprotótipo, de uma imagem aparentemente concluída, a face expressiva de Dora, mas é do diálogo com o seu sofrimento que se compõe uma ideiaforça, que materializa sua existência na obra A mulher que chora (Silveira, 2010). Ele pinta o que consegue captar do diálogo de Dora com o mundo. É 
do encontro das vozes/perspectivas, das consciências, ao mesmo tempo que no contraste de posicionamentos, que se produz a ideia, produzindo-se com isso também a atividade estética, enquanto busca de objetivação expressiva das intensidades de onde a ideia emergiu. Neste sentido, para Bakhtin (2002:86):

O pensamento humano só se torna pensamento autêntico, isto é, idéia, sob as condições de um contato vivo com o pensamento dos outros, materializado na voz dos outros, ou seja, na consciência dos outros, expressa na palavra. É no ponto desse contato entre vozes-consciências que nasce e vive a idéia.

O artista pinta a ideia, que irrompe como ideia-força quando ele consegue escutar a voz/perspectiva de seu outro, dialogando com esta, ao mesmo tempo em que procede a um distanciamento exotópico, em busca de uma visão de conjunto, de reelaboração criativa da relação dialógica vivenciada, experimentada intensivamente, empaticamente, eticamente.

\subsection{A carnavalização}

O conceito de carnavalização encontramos na obra A cultura popular na Idade Média e no Renascimento: o contexto de François Rabelais (2008), quando Bakhtin analisa o problema da cultura cômica popular no âmbito das produções literárias de François Rabelais, situadas no século XVI.

A cultura cômica popular, na Idade Média e no Renascimento, tensionava a cultura oficial, o tom sério, religioso e feudal, e se manifestava em forma de ritos, espetáculos, obras cômicas verbais e diversas formas e gêneros do vocabulário familiar e grosseiro. As festas carnavalescas populares, na praça pública, eram uma forma de manifestação fundamental dos ritos e espetáculos, que se convertiam numa espécie de segunda vida do povo que era vivida durante períodos determinados (em torno de três meses por ano), pois ofereciam uma visão diferenciada do mundo, coexistente com o mundo oficial, mas ignorando dogmatismos e o autoritarismo.

A visão carnavalesca do mundo, que Bakhtin recupera nas imagens da literatura de Rabelais, opõe-se ao princípio monológico da manifestação de 
uma única voz/perspectiva, centrada numa única consciência: é na base da dialogicidade que o carnaval acolhe a todas as vozes/perspectivas, aceita a subordinação do sério ao cômico, festeja a morte e o renascimento, a abolição temporária de todas as verdades e a diluição das hierarquias, estabelecendo novos modos de relação humana.

Durante as festividades carnavalescas criava-se uma forma especial de contato entre as pessoas, mais livre e familiar, sem a existência de barreiras que normalmente separavam as pessoas em grupos incomunicáveis, divididos por classe, por exemplo. O diálogo era aberto a todos e realizado pela utilização de uma linguagem particular, a carnavalesca, a qual Rabelais traz em suas obras. A linguagem carnavalesca era liberada das normas e etiquetas, subvertendo-as, ao mesmo tempo em que recuperava expressões populares proibidas pela cultura oficial.

Desta análise da cultura popular na Idade Média e no Renascimento na esfera das produções de François Rabelais, Bakhtin chega ao conceito de carnavalização, que significa uma transposição do carnaval para a literatura, incorporando a esta os princípios de uma subversão paródica do cotidiano, autorizando a derrocada ficcional, em praça pública, das autoridades oficiais, como reis e papas; significa o renascimento de novas verdades, a diluição das hierarquias, o reconhecimento do inacabamento humano, o desaparecimento do medo resultante das desigualdades sociais, a manifestação do riso jocoso e alegre (Bakhtin, 2008).

Dentre as contribuições da carnavalização como categoria na literatura, desde o ponto de vista de Bakhtin (2002), estão influências sobre mudanças no próprio estilo da literatura, renunciando-se a uma unidade estilística e abrindo-se a possibilidades de uma politonalidade da narração, pela fusão do sério e do cômico e empregando-se gêneros intercalados, como cartas e paródias.

\section{O dialogismo como operador teórico-metodológico}


A constituição do lócus da presente investigação ocorreu a partir de nossa participação na formação continuada de professores dos anos iniciais do ensino fundamental, em situação de serviço, através de um projeto que opera na dimensão da interface pesquisa/extensão, o Civitas, desenvolvido desde 2002 pelo Laboratório de Estudos em Linguagem, Interação e Cognição, da Faculdade de Educação da Universidade Federal do Rio Grande do Sul (LELIC/FACED/UFRGS) ${ }^{2}$.

O projeto Civitas busca contribuir, pela via da formação de professores, para a invenção de uma sala de aula que contemple a inserção criativa das crianças nos processos de aprendizagem através da imaginação (Axt, 2005). Para tanto, investe-se em diversos dispositivos, como a criação de cidades imaginárias, personagens, histórias coletivas e outros.

Atualmente, através deste projeto realiza-se a formação de aproximadamente quarenta professores, vinculados ao sistema público da rede municipal de ensino de quatro municípios do estado do Rio Grande do Sul, os quais firmaram convênio de cooperação pesquisa-formação com a Universidade. Para tanto, os professores dividem-se em pequenos grupos de estudos, incluindo um pesquisador do LELIC que atua também como formador. Os encontros dos grupos são realizados com uma periodicidade quinzenal, em média.

Os grupos iniciam seus encontros em março, concomitantemente com o início das aulas, e os finalizam no mesmo período de encerramento do ano letivo. Nos encontros realizam-se discussões em torno da singularidade contextual de cada turma, bem como das práticas pedagógicas nesses diversos contextos, além da discussão de textos teóricos e registros escritos pelas próprias professoras, que carregam ressonâncias das produções dos alunos.

Quantos aos dispositivos, não há regras para que se instaure um determinado dispositivo, pois a ênfase recai não sobre o que ele é, mas sobre os processos que pode provocar. Nos encontros dos grupos de formação um

${ }^{2}$ Sob a coordenação geral da $\operatorname{Prof}^{\mathrm{a}} \operatorname{Dr}^{\mathrm{a}}$ Margarete Axt. 
dos objetivos é auxiliar a sustentar estes dispositivos durante o ano, para que não se tornem só mais uma atividade pontual com início e fim prédeterminados, mas que durem enquanto se transformam, acompanhando os processos imaginativos das crianças. Ao mesmo tempo, busca-se potencializar as conexões a partir deste dispositivo, ampliando as suas interfaces com os conteúdos curriculares, dentro de um pressuposto de escuta das vozes das crianças, de suas curiosidades, inquietações, indagações.

As crianças podem iniciar construindo uma cidade na sala de aula, inserindo personagens nesta cidade, escrevendo suas histórias, buscando seguir trajetos desviantes da proposta de cópia representacional que dá origem a uma maquete, por exemplo. Também podem iniciar com a leitura de um livro, criando os personagens da história, recontando esta história de diferentes modos até que ela se desvincule do livro e se torne a história das próprias crianças, num percurso de autoria coletiva em que a professora tem a chance de trabalhar diversos conteúdos.

O projeto opera numa perspectiva ético-estético, não somente nos grupos de formação, mas também nas salas de aula, ao investir no cuidado da relação com o outro e no acolhimento da produção de sentidos emergidos nesta relação. Portanto, é no contexto de uma professora participante do projeto Civitas, juntamente com seu grupo de alunos de terceiro ano, que se realizou a presente pesquisa (Silveira, 2010). Nesta direção, o intuito da pesquisa é traçar percursos de abertura de espaços de criação na sala de aula através de dispositivos-personagens.

Pontuamos que os materiais dos quais dispomos com o fim de realizar as análises consistem em textos produzidos nos diálogos na sala de aula da turma que acompanhamos ou, ainda, nos registros escritos no diário de campo da pesquisa ${ }^{3}$. Segundo Bakhtin, os textos são o dado primário das ciências humanas: “Onde não há texto não há objeto de pesquisa e

\footnotetext{
${ }^{3}$ Na pesquisa também utilizamos, para compor as análises, o diário de campo produzido pela própria professora do terceiro ano, porém, no presente artigo, tendo em vista a sua limitação de espaço, não apresentamos este material.
} 
pensamento” (Bakhtin, 2003:307). Trabalhamos com textos orais e escritos, compreendendo-os como enunciados, na acepção bakhtiniana. Destacamos, assim, os tipos de registros que compõem nosso material de análise:

Diário de campo da pesquisa (DPe): foi utilizado como suporte para uma escrita com vistas a traçar os movimentos interacionais entre alunos e professora, em sala de aula, e entre as professoras participantes do projeto Civitas em uma escola, nos seus encontros do grupo de estudos e formação. Através da participação da pesquisadora no grupo de estudos, tornou-se viável o acompanhamento dos percursos da turma de terceiro ano através dos relatos da própria professora, os quais eram registrados no diário da pesquisadora, antes mesmo de sua efetiva entrada na sala de aula.

$\mathrm{Na}$ sala de aula, os registros foram realizados durante os meses de setembro a dezembro, semanalmente, quando aconteciam as inserções da pesquisadora na sala, para a realização de filmagens das interações entre professora e alunos. No grupo de estudos, os registros foram realizados desde o primeiro até o último encontro, de março a dezembro de 2008.

Transcrição das filmagens em sala de aula (Tr): As transcrições foram realizadas a partir de filmagens das interações verbais entre professora e alunos, na sala de aula. Analisamos as transcrições de duas aulas, que aconteceram nos dias 11 de novembro e 03 de dezembro, em que os alunos trabalhavam com a criação de personagens. Consideramos, nas transcrições, que os enunciados são marcados pela alternância das falas dos sujeitos. Estes enunciados são referidos, nas análises, como $\operatorname{TrF} x$, que indica: $\operatorname{Tr}=$ transcrição; $F$ = formulação; $x$ = número da formulação (ou seja, linha em que se encontra o enunciado, na transcrição). Inclui-se, ainda, à sigla $\operatorname{TrFx}$, a indicação $a$ ou $b$, onde $a$ refere à formulação pertencente à transcrição realizada em novembro ( $\operatorname{TrF}$ xa), e $b$ refere à formulação pertencente à transcrição realizada em dezembro $(\mathrm{TrF} x \mathrm{~b})^{4}$.

\footnotetext{
${ }^{4}$ As transcrições obedeceram ao seguinte critério de identificação dos falantes: $P$ Professora; Vários - quando vários alunos falam ao mesmo tempo, sem condições de identificar os falantes; Não identificado - quando não foi possível identificar o falante,
} 
Por meio dos tipos de registros citados foram criadas as condições para visibilidade das cadeias de enunciados a serem analisadas. É importante destacar que o recorte dos enunciados nos vários registros vai se ater mais especificamente a uma determinada situação, que se trata do processo de criação de personagens pelos alunos e pela professora.

A arquitetura de análise dos textos tem como operador teórico central o conceito de dialogismo em Bakhtin, considerando-se o diário de campo da pesquisadora e as transcrições das interações verbais em sala de aula como registros visíveis das cadeias dialógicas de enunciados. Nesta perspectiva, analisamos os enunciados em seus aspectos responsivos/responsáveis, ou seja, com foco no modo como cada enunciado vem a responder a outro, nas suas conexões que configuram as relações dialógicas.

\section{Releituras da sala de aula e a produção de novos sentidos}

É comum nas escolas, logo no início do ano letivo, a escolha de um tema geral a partir do qual é formulado um projeto do tipo "guarda-chuva”, gerando atividades específicas em cada turma, na dependência das relações com o planejamento de cada professora. No caso da escola em que se realizou o presente estudo, o tema escolhido para o projeto anual, em 2008, foi $O$ mundo tem o tamanho dos seus sonhos. A professora responsável pela turma de terceiro ano da escola, professora $\mathrm{Ta}$, manifestou interesse em desenvolver o trabalho pedagógico em sala de aula de maneira articulada com tal tema.

A professora Ta selecionou um livro de literatura infantil, Os pregadores do Rei João. O livro de Luís Camargo (1985) conta a história de um lençol mágico que pertencia a um Rei chamado João. A partir da leitura do livro, a professora pensou que a turma poderia produzir um personagem, o lençol mágico, e que este seria constituído a partir dos desenhos de

devido a problemas de qualidade na gravação ou intensidade de ruídos. Quanto aos alunos, todos tiveram seus nomes substituídos por nomes fictícios. 
sonhos, feitos pelos alunos, diretamente em um tecido. Assim, o lençol mágico viajaria para lugares diversos, carregando as marcas dos sonhos dos alunos. As histórias destas viagens seriam escritas pelos alunos e, a partir das quais a professora pretendia desenvolver os conteúdos curriculares.

Este é um primeiro movimento da professora Ta, uma ideia que consistiu na criação de um personagem, tendo em vista a articulação entre o tema da escola, a literatura infantil e, ainda, o projeto Civitas, do qual estava participando. Tal movimento inicial de produção da ideia, vivenciado pela professora Ta, nos remete ao movimento de produção da ideia dos personagens nos romances de Dostoiévski. Emerge uma primeira ideia, a criação de um lençol mágico, uma ideia-protótipo que provém da observação que a professora Ta faz de seu contexto, da instituição, do projeto anual da escola.

Ao considerarmos a primeira ideia de criação de um personagem, o lençol mágico, como uma ideia-protótipo, visualizamos a possibilidade de que esta ideia se torne ideia-força, na interação entre alunos e professora, assumindo-se a complexidade do diálogo com o outro, e possibilitando que se instaure a voz/perspectiva do outro-criança como constitutiva de sua existência.

Abaixo apresentamos uma figura dos alunos em torno do lençol mágico, já em processo de constituição:

Figura 1: O lençol mágico 


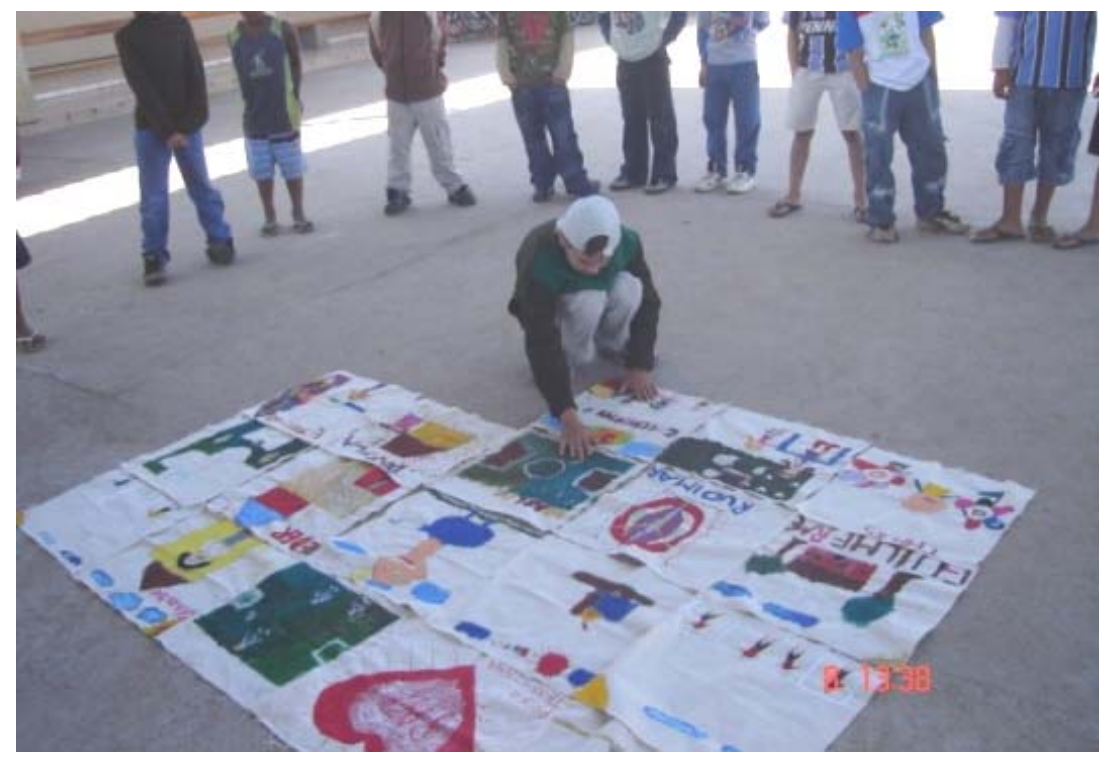

Fonte: Arquivo do projeto Civitas, $2008^{5}$.

Identificamos, a partir dos relatos da professora Ta, no grupo de estudos (conforme DPe, em período anterior à entrada da pesquisadora na sala de aula, propriamente), um conjunto de três etapas a partir das quais se constituiu, inicialmente, o trabalho com o personagem lençol mágico: (i) pintura dos sonhos no tecido, pelos alunos; (ii) costura dos tecidos com a participação das famílias; (iii) viagem do lençol mágico pelos lares dos alunos, acompanhado de um diário.

Neste caso, a possibilidade de antecipação e organização das etapas, pela professora, como ocorrido, indica que a criação do personagem opera ainda na instância da ideia-protótipo, visto que há uma consciência que a direciona, ao tentar prever as condições da interação com o outro, logo, a resposta deste outro.

\subsection{A viagem do lençol mágico}

Numa observação realizada pela pesquisadora, no mês de setembro, agora no espaço da sala de aula, a professora ligou o rádio e pôs a tocar uma música, convidando os alunos a realizarem uma viagem no lençol mágico. Entregou um saco de pano para um aluno, para a realização de um jogo: o saco deveria ser passado entre os alunos, e assim que a música parasse o

\footnotetext{
${ }^{5}$ Imagem registrada pela professora Ta.
} 
aluno que estivesse com o saco deveria retirar um objeto do mesmo. Logo após, deveria contar uma história a respeito de como aquele objeto estava embarcando na viagem com o lençol mágico.

Dentro do saco havia objetos como animais de borracha e acessórios relacionados às tradições gaúchas, como cuia, bomba de chimarrão, lenço de pescoço, sendo que estes últimos haviam sido colocados intencionalmente no saco, pela professora Ta, que tinha em vista o objetivo de relacionar o jogo a um trabalho sobre as tradições gauchescas. Todavia, nenhum dos objetos retirados do saco pelos alunos estava entre aqueles que a professora esperava, o que alterou a proposta planejada de trabalho.

O primeiro objeto retirado foi um sapo. A aluna Aline contou que a turma encontrou o sapo na rua, durante o desfile de sete de setembro, e que o sapo subiu no lençol mágico para embarcar na viagem. Abaixo segue um trecho deste diálogo, registrado diretamente no DPe.

\begin{tabular}{|ll}
\hline Aline & Um sapo. \\
P & Onde tu acha que o lençol pode ter viajado que ele encontrou um sapo? \\
$\mathrm{P}$ & No desfile. \\
Ali & Tu acha que ele encontrou o sapo no desfile? \\
$\mathrm{P}$ & Sim. \\
Ali & Então conta a história. \\
$\mathrm{P}$ & Lá na rua. \\
$\mathrm{NI}$ & E o que será que o sapo estava fazendo lá no desfile? \\
$\mathrm{P}$ & Tava olhando o desfile. \\
\hline
\end{tabular}

Para Aline, o lençol mágico viajou pelo desfile, onde encontrou o personagem sapo. A professora responde a este enunciado realizando um movimento de compenetração na história, dialogando com a voz/perspectiva da criança, quando diz: E o que será que o sapo estava fazendo lá no desfile?, Ou será que era um desfile de sapos?. Nesta situação se constitui uma relação ética da professora com a aluna baseada numa atitude de escuta à sua voz/perspectiva; mas também da criança, ao entrar no jogo planejado e proposto aos alunos pela professora. 
O segundo objeto retirado do saco, pelo aluno Edmar, foi um cavalo, e o terceiro, retirado por Daniela, um jacaré. Por último, o aluno Marcelo retirou do saco um passarinho que, segundo ele, foi encontrado numa floresta. A professora questionou a turma se eles poderiam levar o passarinho no lençol mágico, visto que o estariam retirando de seu ambiente natural. Os alunos decidiram que então ele não poderia embarcar no lençol mágico. Porém, o problema da retirada do animal do seu ambiente natural foi logo resolvido pela aluna Daniela, que se levantou do espaço em que estava sentada no lençol mágico, mostrando para a turma uma árvore que estava pintada no tecido. Tratava-se da árvore pintada pela aluna Giovana, que representava o seu sonho de cuidar da natureza. A aluna Daniela afirmou que o passarinho poderia habitar aquela árvore. Todos se levantaram para ver o desenho, e encontraram mais uma árvore, logo concordando que nela também poderia viver o passarinho.

Para o sapo, o cavalo e o jacaré não haviam sido encontrados ambientes adequados no lençol mágico, tal como para o passarinho. A partir da sugestão da professora, os alunos, divididos em grupos, produziram o passarinho, o cavalo, o jacaré e o sapo bem como os seus respectivos ambientes, utilizando materiais recicláveis.

Na realização do jogo proposto pela professora Ta observa-se uma tensão entre a possibilidade de antecipação e a imprevisibilidade da resposta do outro, nas interações dialógicas. A ideia da professora, de trabalhar as tradições gaúchas, ganhou um novo movimento na interação entre as consciências. No espaço interacional viabilizado pelo jogo, instalou-se uma condição de imprevisibilidade, de algo que escapou ao controle da professora. Portanto, é importante deter-nos no modo como a professora lida com esta imprevisibilidade, pois, diferentemente do que havia sido por ela planejado, na tentativa de inserir um determinado tema nas histórias da viagem com o lençol mágico, foi um desvio provocado pelo interesse dos alunos nos animais que ganhou destaque. 
Com Bakhtin (2003), compreendemos que é na diferença que se fundamenta o trabalho de criação, entendendo-se a criação como o processo de dar sentido ao outro, um sentido sempre diferente, marcado pela sua singularidade. Para ele, o autor, ao ambientar o personagem levando em conta a conjuntura de seu mundo de relações (arquitetônica relacional), dá sentido à existência do outro, singularizando-o. É a partir desta possibilidade do autor, de completar o outro, que nasce da diferença de posições que autor e personagem ocupam, gerando-se um excedente de visão do autor sobre o mundo do outro-personagem, que se realiza a criação estética.

O acabamento produzido pelo autor, porém, não aprisiona a obra, o personagem, o texto. Bakhtin entende este ato do autor como um ato éticoestético, um ato generoso, de quem completa o outro com algo que é seu, com algo que somente ele poderia oferecer, ou seja, sua perspectiva particular e única do mundo. O personagem se constitui no discurso do outro, no olhar do outro, que lhe atribui sentido e vida. O olhar do outro, do autor, extrai o personagem do puro movimento, onde ele tudo pode vir a ser, ao completá-lo provisoriamente com seu excedente de visão.

O personagem lençol mágico se transforma, a partir de um novo olhar da criança sobre ele, produzindo novos sentidos. A partir disso, o lençol mágico torna-se um ambiente para outro personagem, o passarinho. Podemos dizer que, nesta situação de experimentação vivenciada pela professora Ta e pelos alunos, houve condições para a produção de sentidos e para a atividade estética. A escuta que a professora Ta faz do inusitado, enquanto implicada/compenetrada na situação de experimentação, opera como um mergulho no mundo de possibilidades do outro, constituindo o seu aluno como outro, ao qual responde, propiciando, pela ampliação de sua visão sobre o potencial criativo de seus alunos, a instauração de suas vozes/perspectivas na sala de aula. De igual modo, as crianças escapam do planejado aproximando-se dos mundos relacionais dos brinquedos de borracha (pequenos animais), para completá-los com novos sentidos a partir 
de uma contemplação desses mundos, assim enriquecendo esteticamente a história do lençol mágico.

\section{2. $O$ mundo carnavalizado dos personagens}

Após o acontecimento da viagem do lençol mágico, com a inserção dos animais, cada aluno passou a produzir algum animal e seu habitat, de acordo com a sua escolha. Realizamos filmagens, na sala de aula, no dia de realização destas produções, em 11 de novembro de 2008. Para tanto, foram utilizados, pelos alunos, diversos materiais recicláveis e outros tipos de materiais, como tinta e papel colorido (conforme figura 2). 
Figura 2: Os animais

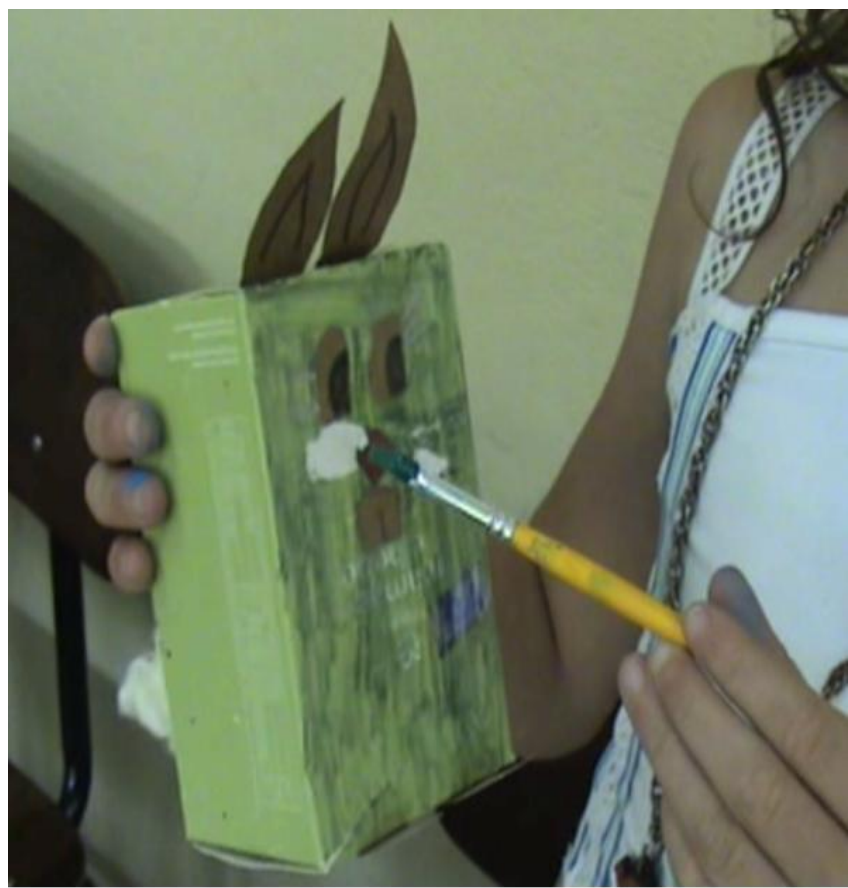

Fonte: Arquivo do projeto Civitas, 2008.

A professora Ta convidou os alunos a apresentarem seu animal à turma, informando se gostaria que o animal embarcasse no lençol mágico ou se ele viveria no seu respectivo habitat. Também abriu a possibilidade de que os alunos fizessem perguntas uns aos outros. A apresentação seguiu a ordem de posicionamento das classes e cadeiras em que cada um estava sentado, na sala de aula. Neste contexto, a professora regula a interação, sendo ela quem organiza os turnos de fala, conforme se observa no segmento 1.

Segmento 1

\begin{tabular}{|c|c|c|}
\hline 22 & $\mathrm{P}$ & $\begin{array}{l}\text { Vanessa! } \\
\text { A aluna Vanessa se dirige ao centro da sala levando seu animal }\end{array}$ \\
\hline 23 & Vanessa & A idade dele é oito \\
\hline 24 & $\mathrm{P}$ & $\begin{array}{l}\text { Se alguém quiser fazer uma pergunta sobre o animal dela, só tem que levantar } \\
\text { o dedo, tá? Fala Diego! }\end{array}$ \\
\hline 25 & Diego & $\begin{array}{l}\text { [não identificado] } \\
\text { Fabiana levanta a mão }\end{array}$ \\
\hline 26 & $\mathrm{P}$ & Fabiana! \\
\hline 27 & Fabiana & Ela tem filhos? \\
\hline 28 & Vanessa & Sim \\
\hline 29 & Fabiana & Quantos? \\
\hline
\end{tabular}


Observa-se que as intervenções realizadas pela professora voltam-se quase exclusivamente para a administração da interação. Nas TrF 22a, 24a, 26a, 32a, a professora intervém enunciando o nome de algum aluno, para autorizá-lo a falar. A professora tem a intenção de que todos os alunos participem, apresentando os seus animais. Esta intenção orienta a interação, administrada pela professora, que organiza a seqüencialidade dos turnos de fala de acordo com a posição dos alunos em sala de aula, num primeiro momento, e depois passa a regular também a realização de perguntas, pelos alunos, sobre os animais apresentados pelos colegas.

A professora busca direcionar sua atenção à voz/perspectiva do aluno, criando as condições para que todos possam falar. Porém, há um tensionamento entre o propósito de escuta da voz/perspectiva do aluno e sua intenção de ordem democrática e conclusibilidade. No anseio de que todos possam participar, a professora organiza a interação, demarcando o início e fim dos turnos de fala. Em algumas situações ela conclui a apresentação do aluno, para que logo outro aluno possa falar, conforme se verifica nas $\operatorname{TrF} 84 \mathrm{a}$, segmento 2.

\section{Segmento 2}

$\begin{array}{lll}61 & \text { Aline } & \begin{array}{l}\text { É uma coelha, o nome dela é Fofa, ela, ela, mora num jardim. Ela tem uma } \\ \text { entrada que eu fiz, tem alimentos }\end{array} \\ 62 & \begin{array}{l}\text { Não } \\ \text { identificado }\end{array} & \text { Fala mais alto! } \\ 63 & \text { Aline } & \text { Também tem bastante verde } \\ 64 & \text { P } & \text { Tem que escutar o que ela tá falando, não vale perguntar o que ela já falou } \\ 65 & \text { Aline } & \text { E flor, tem coisa pra brincar, tem um monte de coisa } \\ 66 & \text { P } & \text { Fabiana! } \\ 67 & \text { Fabiana } & \text { Tem filhos? } \\ 68 & \text { Aline } & \text { Tem } \\ 69 & \text { Vanessa } & \text { Quantos? } \\ 70 & \text { Aline } & \text { Um }\end{array}$




\begin{tabular}{|lll}
71 & Vanessa & Onde eles tão? \\
72 & Gustavo & Dentro da barriga \\
73 & P & Quem vai responder é ela. Edmar! \\
74 & Edmar & Ô sora, por que ele não tem bigode, sôra? \\
75 & Aline & Eles arrancaram \\
76 & P & Que triste né? \\
77 & Juliano & Qual é o nome do filho? \\
78 & Aline & É Bruno \\
79 & Juliano & E os dente? \\
80 & Aline & Ãh? \\
81 & Juliano & E os dente? \\
82 & Aline & Tá aqui \\
83 & Juliano & Como é que são os dente? \\
84 & P & Tá de boca fechada né Aline? Letícia!
\end{tabular}

A partir deste segmento observa-se também que se configuram, no curso dos diálogos, diversas brechas que a professora poderia ter aproveitado para estender as possibilidades conceituais e de sentido, trabalhando os conteúdos curriculares com os alunos, mas ela aparece capturada pelo objetivo de que todas possam participar, fixando-se na conclusibilidade das falas e, com isso, não observando as diversas possibilidades de problematização de acordo com as temáticas que surgem, como a reprodução e a alimentação animal (conforme observa-se no segmento 3) .

\section{Segmento 3}

$\begin{array}{lll}103 & \text { Gustavo } & \text { O que que ele gosta no seu ambiente natural e o que que ele mais, se ele já } \\ 104 & \text { Anderson filhos } & \text { Ele não tem filhos, ele mora na fazenda } \\ 105 & \text { Gustavo } & \text { E o que que ele gosta no ambiente natural? } \\ 106 & \text { Anderson } & \text { Da fazenda } \\ 107 & \text { P } & \text { Aline! Terceira pergunta } \\ 108 & \text { Aline } & \text { Que tipo de coisa ele come? }\end{array}$

No quadro dos estudos bakhtinianos, encontramos na obra A cultura popular na Idade Média e no Renascimento: o contexto de François Rabelais (2008), uma via de análise deste processo vivenciado pela 
professora Ta com seus alunos. O carnaval é um evento que se tornou um conceito, no campo da análise literária, a partir desta obra bakhtiniana. No carnaval analisado por Bakhtin, no período da Idade Média e do Renascimento, prevalece uma afirmação do diferente, vislumbrando-se sempre que outro mundo é possível. A ênfase nas imagens do baixo corporal remete ao desejo de mudança que vem de baixo.

No carnaval, contempla-se o corpo nas suas brechas e aberturas. O corpo cristão idealizado perfeito e acabado é rebaixado pelo ponto de vista que constrói a imagem grotesca. É a morte do sujeito asséptico vinculado à ideia de acabamento e perfeição, operando-se com as imagens escatológicas como algo alegre e bem humorado.

É importante lembrar que o carnaval acontecia como uma festa popular, em períodos determinados, que duravam cerca três meses (Bakhtin, 2008:11). Assim, o próprio carnaval era uma brecha na sociedade medieval autoritária e dogmática, tal como a boca é uma brecha no corpo grotesco. Era a abertura para um segundo mundo e uma segunda vida do povo, coexistente com a cultura oficial, ainda que se constituísse como "uma fuga provisória dos moldes da vida ordinária” (Bakhtin, 2008:06).

Desta forma, entendemos que se produz uma brecha justamente porque existe um corpo, seja o corpo físico, ou um corpo social, por exemplo. O corpo fechado, monológico, é a condição de existência da própria brecha, a partir da qual se instaura um mundo carnavalizado.

No que concerne ao trabalho dos alunos e da professora Ta em torno dos animais, não houve uma imersão nas diversas brechas que se abriram durante a interação, oportunidades para desenvolver conteúdos curriculares destacados. Porém, é importante observar que a professora abre espaço para a produção da criança, sustentando um compromisso com a escuta da sua voz/perspectiva. Entendemos que a abertura deste espaço para que os alunos participem, apresentando seus animais, realizando perguntas, é um primeiro movimento que cria as condições para que se constituam as brechas, logo, 
um movimento em direção às possibilidades de carnavalização no processo de criação de personagens.

A criação de possibilidades de interação é um primeiro movimento em direção a uma idéia de “carnavalização” das relações na sala de aula, abrindo-as à dialogicidade, num percurso em que emergem diversas brechas, enquanto acontecimento inusitado. Ainda que estas brechas não tenham sido aproveitadas, em diversas situações, a sua emergência é indicador de que há um espaço para os alunos, na sala de aula, manifestarem as suas vozes/perspectivas, as suas ideias, e que, ao encontro das ideias da professora, poderão operar no processo de constituição de ideias-força.

\subsection{O mutante}

O mutante é um personagem que a professora cria e envia para a sala de aula (na aula do dia 03 de dezembro de 2008), carnavalizando o trabalho com os animais, ao inserir neste contexto um animal exótico, que tem rabo de peixe, perna de peru e cabeça de gato. A professora Ta produziu este animal, de papel, e enviou para a sala de aula dentro de uma caixa, juntamente com uma carta que ela elaborou. Na caixa estavam colados selos, como se a mesma tivesse chegado até à escola pelo correio.

No dia de surgimento do mutante, a professora vice-diretora da escola bateu à porta da sala de aula e disse que havia chegado uma encomenda na escola, para a turma do terceiro ano. Os alunos levantaram-se e se dirigiram à porta. A caixa foi recebida pela professora Ta, que a colocou sobre uma classe. Dois alunos abriram a caixa, e lá encontraram o animal mutante juntamente com uma carta. A carta dizia:

CAROS AMIGOS DO TERCEIRO ANO, VIM LÁ DA TERRA DO REI JOÃO, ONDE VIVIA O LENÇOL MÁGICO, LEMBRAM? COM ELE VIAJEI POR VÁRIOS LUGARES, PASSEI POR SANTA CATARINA E DEVIDO AOS DESASTRES ECOLÓGICOS QUE ESTÃO ACONTECENDO POR LÁ SOFRI MUTAÇÕES, AGORA PRECISO ENCONTRAR UM AMBIENTE ONDE CONSIGA ME ADAPTAR E SOUBE QUE POR AQUI TAMBÉM EXISTE UM LENÇOL, HÁ VÁRIOS AMBIENTES. POR FAVOR ME AJUDEM A ENCONTRAR UMA CASA ONDE POSSA ME 
ADAPTAR MELHOR. DESDE JÁ AGRADEÇO, POIS SEI QUE PODEREI CONTAR COM VOCÊS.

O enunciado-carta opera como uma ideia-protótipo, pois quando a professora escreve preciso encontrar um ambiente onde consiga me adaptar e soube que por aqui também existe um lençol, há vários ambientes. Por favor me ajudem a encontrar uma casa onde possa me adaptar melhor, há uma intencionalidade implicada. O seu objetivo era de que os alunos encontrassem o ambiente mais adequado para o mutante, entre os ambientes que eles já haviam produzido para os seus próprios animais, aprofundando o estudo em ciências ambientais.

No entanto, embora seja perceptível a força desta intencionalidade no curso do diálogo, logo a professora abre um espaço para as crianças na criação de um nome para o animal mutante.

Os alunos sugerem diversos nomes (como Bichano, Mutante, O estranho, Bicho Misturado, Peixe Lebre Gato...), assim como um aluno sugere que seja realizada uma votação para a escolha do nome do animal mutante. A professora Ta, ao abrir este espaço para os alunos, que se posicionam, manifestando sua voz/perspectiva ao vivenciarem o processo de criação do nome do animal, também se implica neste processo, como pode ser visto na $\operatorname{TrF} 149 \mathrm{~b}$ (segmento 4).

\section{Segmento 4}

\begin{tabular}{|ll}
144 P & Pra gente fazer a votação a gente vai ter que votar não pelo o que o colega \\
145 Giovana & Mutano sôra \\
146 P & Mutano? \\
147 João & Mutano só se fosse uma pessoa com super poderes \\
148 Amanda & Sôra, eu sei mais um. Eu sei o gato com rabo de peixe e perna de peru \\
149 P & Escuta, e será, será que o nosso animal não tem super poderes? \\
150 João & Ele não tem poder \\
151 P & Ah? \\
152 João & Ele não tem poder \\
153 P & Será que não? \\
154 Não identificado & Tem, tem \\
155 Não identificado & Nadador
\end{tabular}




\begin{tabular}{|ll}
156 Amanda & Oh sôra, eu sei um nome que, eu sei um nome que é gato com rabo de \\
157 P & peixe e com perna de peru \\
158 Amanda & Como é que é o nome? \\
159 P & Cabeça de gato com rabo de peixe e com perna de peru \\
160 Vários & Esse é o nome? \\
161 Amanda & Ah
\end{tabular}

Na TrF 149b, quando a professora diz: Escuta, e será, será que o nosso animal não tem super poderes?, ela demonstra uma implicação no processo criativo das crianças, dialogando com as suas vozes/perspectivas. A professora responde ao enunciado de João ( $\operatorname{TrF} 147 \mathrm{~b}$ ), novamente abrindo uma possibilidade para a carnavalização do personagem.

\section{Considerações finais}

No curso das produções na sala de aula que acompanhamos havia condições, de um lado, para a criação estética (através de personagens compondo com seus ambientes); e, de outro, para a criação de conhecimentos (a respeito da reprodução e alimentação animal, por exemplo, aprofundando estudos sobre ciências ambientais e biológicas), conforme as diversas brechas que emergiram no curso das interações. No entanto, parece que estas duas vias da criação foram pouco exploradas pela professora, na medida em que ela estava concentrada no gerenciamento da interação, perdendo-se em diversas situações a sua abertura para o ato ético de uma escuta das vozes/perspectivas das crianças.

Entendemos, todavia, que houve condições para a emergência das brechas, possibilitando a manifestação de vozes/perspectivas na sala de aula, em diferentes momentos, sendo o personagem, no papel de intercessor (mediador de passagem), o lugar de instituição destas vozes. Por outro lado, a captura da atenção da professora pelo gerenciamento da interação, colocou-a parcialmente no controle de caráter monológico deste lugar. 
Já os personagens se constituíram a partir do espaço aberto para a relação dialógica. Este é o lugar do ato ético, de uma escuta e acolhimento das vozes/perspectivas em processo. A amplitude, maior ou menor deste espaço de abertura, irá depender do exercício de uma escuta do contexto, de um acolhimento das vozes/perspectivas que insistem em se colocar na corrente da relação dialógica.

O aproveitamento de brechas para a criação estética e epistemológica se viabiliza na medida da amplitude da abertura propiciada. Quando a professora entra na sala de aula com uma ideia-protótipo em alto grau de acabamento é com dificuldade que ela pode proceder a uma escuta das vozes/perspectivas em vias de se instaurarem. Neste caso, predomina a busca de respostas convergentes e o gerenciamento da interação em vista de um objetivo previamente definido pela professora.

Uma ideia-força tem potência para se produzir a partir de uma ideiaprotótipo na medida em que esta se insere no novo contexto (da sala de aula) como uma ideia inacabada, aberta à relação dialógica, ao acolhimento dos sentidos do outro. É nesta dimensão que o espaço de abertura se amplia e se produz com intensidade o ato ético. Ao mesmo tempo, é o exercício do afastamento contemplativo que o professor é capaz de efetuar simultaneamente à escuta, o que lhe oportuniza, pelo excedente de visão momentâneo, capturar o inusitado, o desvio, o imprevisível, as brechas percebendo-os como parte de um todo em movimento, o pensamento curioso, espontâneo, imaginativo a ser investido de potência em busca do conhecimento.

Consideramos a importância de dar visibilidade a este movimento de instauração do ato ético, mostrando a complexidade de um trabalho pedagógico que opere com as dimensões amplificadas da escuta e que viabilize a instauração de vozes/perspectivas dos alunos; e que, simultaneamente possa realizar, ao conjunto do movimento em sala de aula, um olhar contemplativo que lhe aponte, pelos desvios e pelas brechas, as 
direções nas sendas do conhecimento em se fazendo, no processo do Ser em devir.

Em outras palavras, afirma-se, para nós em educação, o sentido de que uma prática pedagógica (mesmo quando inicialmente idéia-protótipo) devém idéia-força com potência criadora contagiando e enriquecendo a sala de aula, sempre que, na interação dialógica (e carnavalizada) com o desviante, agir e contemplar se entrelacem e se sustentem mutuamente, durando no Ser em processo: a via contemplativa abre, então, espaço a uma estética (in)acabada do olhar, na dobra de um agir que se inscreve como ética (in)tensiva da escuta, produzindo condições de possibilidade para o imaginar, o aprender, o conhecer, o cooperar.

\section{Referências}

AMORIM, Marília. Cronotopo e exotopia. In: BETH, Brait (org). Bakhtin: outros conceitos-chave. São Paulo: Contexto, 2006.

AXT, Margarete. CIVITAS: abrindo espaços de invenção da escola. In: MOLL, Jaqueline (org.). Múltiplos alfabetismos: diálogos com a escola pública na formação de professores. Porto Alegre: Editora da UFRGS, 2005.

AXT, Margarete. Mundo da vida e pesquisa em educação: ressonâncias, implicações, replicações. 2011. (no prelo)

BAKHTIN, Mikhail. Para uma filosofia do ato. Tradução de Carlos Alberto Faraco e Cristóvão Tezza (s/d), diretamente da edição americana Toward a Philosophy of the Act publicada por Vadim Liapunov em Austin, University of Texas Press, 1993.

BAKHTIN, Mikhail. Problemas da poética de Dostoiévski. Rio de Janeiro: Forense Universitária, 2002. $3^{a}$ edição.

BAKHTIN, Mikhail. Estética da Criação Verbal. São Paulo: Martins Fontes, 2003.

BAKHTIN, Mikhail. A cultura popular na Idade Média e no Renascimento: o contexto de François Rabelais. São Paulo-Brasília: Hucitec, 2008.

SILVEIRA, Paloma Dias. Da formação docente em serviço aos espaços de criação em sala de aula. Dissertação de mestrado defendida no Programa de Pós Graduação em Educação da UFRGS: 2010. 
SOBRAL, Adail. Ético e estético: na vida, na arte e na pesquisa em ciências humanas. In: BRAIT, Beth (org.). Bakhtin: conceitos-chave. São Paulo: Contexto, 2007, $4^{\mathrm{a}}$ ed. 